\title{
Humour as a strategy for news delivery: the case of Meduza
}

\author{
Viktoria Vasileva
}

St Petersburg State University

v.v.vasilieva@spbu.ru

\section{Liubov Ivanova}

St Petersburg State University

l.y.ivanova@spbu.ru

\begin{abstract}
In this article, humour is viewed as a strategic resource for informing in media discourse. It is analysed through the case of "Evening Meduza", a Russian-language nightly newsletter, received via email or Telegram messenger. A media linguistics analysis of polycode hypermedia text is used to identify communicative linguistic means, contributing to a comic reinterpretation of news on the paratextual, intratextual and visual-illustrative level. News messages in the newsletter are created in the format of compressed "packagings" (a term borrowed from Chafe) with embedded links, following which an addressee goes to the page with source text or concomitant informational resources. Humour is analysed in packagings as well as in whole text and paratext blocks. Humorous means are revealed in three vectors of analysis: empathy in packaging texts, paratextual focus interaction, and news visualization. The change of narrative perspectives in text packages allows the authors to shift the focus of contrast within a newspiece and create humorous content while showing empathy to readers with different presuppositional expectations. The author's signature always includes a prepositive ironic addition (attribution) that highlights one of the issue's news elements and forces the audience to reread the newsletter in order to understand the semantic relation. Subheadings create a comic contrast, focusing on individual parts of the reference content while preparing the reader to perceive the news of the day interconnectedly. A mandatory humorous component in the block "And-picture" was found to show the news event in a visual semiotic code using a demotivator style that expresses a pun.
\end{abstract}

Keywords: medialinguistics analysis, tools of humour, humour in news, paratext, polycode. 


\section{Introduction}

Our observations of the dynamics of communicative and speech organization in Russianlanguage media show the active penetration of humour into media texts. It is in the comic that journalists are actively looking for ways to increase impact effectiveness, and the creative potential of professional activity is revealed intensively in this way. Our interest is focused on news media texts in network environments, which means the sphere of the latest news messages distributed to a wide audience, forming the audience's idea of the world around us here and now. At the same time, there is a continuous search for strong and bright ways to attract audiences, hold their attention and - the highest prize - to convince.

Extremely widespread use of the comic in modern mass media is noted by many researchers (Baum 2003; Hunt 2013; Alonso 2016; Mann 2016; Chattoo \& Green-Barber 2018; Collins 2018). Comic meanings in the media are born from the communicative needs peculiar to a particular type of professional socio-cultural activity and realize the goals and objectives of such activities. In journalism, these comic meanings serve to orient the audience to the perspective of a particular media.

The basic approach in our study is to recognize that the comic is used in the media to solve concrete communicative tasks. In other words, we suggest that the factors of the comic's appearance should be searched for within concrete instances of media communication which are designed to inform - for instance, in various acts of highlighting a news event ${ }^{1}$. In our opinion, the use of humour can be analysed as a strategic informational element in news media.

It is important to note here that we do not mean the use of humour for making the news more attractive or easy to understand, as primarily emphasized by certain researchers (Baum 2003; Xenos \& Becker 2009; Chattoo \& Green-Barber 2018). We are interested neither in the appropriation of the news as a special comic genre (in stand-up comedy, for example) or in satirical television programs (Hutchings 2007; Hunt 2013; Splendore \& Domaneschi 2017), nor in the use of humour in fake news (Peifer \& Myrick 2019). We want to explore the "invisible" tools of humour (or tools of "invisible" humour), that give news media a special personality and colour agenda in an ironic tone - all of which does not ease, but deepens the content, makes the news more significant or relevant for the day, at least from the point of view of the editors. Humour seems to draw news events into a more vivid relationship with life. This feature of humour is noted by some researchers (section 2). In the Russian-language online news media Meduza.io (see section 3.1.1) we see precisely such an attitude to humour.

Meduza is a media outlet that works, on the one hand, as a news aggregator and on the other, as a fully-fledged journalistic editorial office with its own principles and daily agenda which are actively promoted on the network and mobile versions. The focus of our research is the materials produced in Evening Meduza - a daily newsletter which is a short news feed and, in fact, the evening edition of the newspaper (see section 3.1.2).

From the linguistic viewpoint, we consider each issue as a hypermedia text (Duskaeva et al. 2018) in which individual news reports appear as compressed texts. These separate texts in the issue have features of text-packaging ("packaging" is a concept formulated by Chafe), the unpacking of which is carried out by the reader according to the conventions of online communication. Our study seeks to substantiate the media-linguistic approach to humour, especially in news media (see section 3.1.3.).

The main goal of our study is to identify, with the help of media-linguistic analysis (see section 3.2.), communicative speech tools that carry out or promote the comic reinvention of the news events in the hypertext edition of Evening Meduza. Since Meduza itself does not keep an archive of its materials, we turned to a resource which stores issues of various Telegram 
channels, including the archive of Evening Meduzal. We formed two card files of empirical materials from April and May 2019 using continuous sampling amounting to 40 hypermedia texts (issues) and 210 text-packagings ${ }^{2}$.

\section{The study of humour in relation to news: the scientific context}

Studies of verbal humour are impossible without reference to the development of the most authoritative school of linguistics which is cognitive linguistics. Within this school, the scriptbased semantic theory of humour (SSTH) of V. Raskin (Raskin 1985) was created and subsequently modified by S. Attardo in General Theory of Verbal Humor (Attardo 1994). For our study of humour in news discourse, the scenarios proposed by these researchers for the disclosure of comic dissonance (arising from the collision of opposite scripts) are extremely crucial.

It is important to understand that humour is embodied in media discourse of different forms and amounts: from humorous works in the fields of art or oral folk jokes to the subtle inclusion or manifestation of comic modality in analytical or informational media texts. Clearly, researchers give their attention to purely humorous works: comedy shows, sitcoms, radio comedy, cartoons, anecdotes in periodicals, which examples of how media is used for the functions of leisure or relaxation. Authors analyse humorous media content whether or not the joke, particularly when connected to some public phenomenon, is ethical or not (Lim \& Moufahim 2015; Collings 2018), thus investigating the peculiarities of the satirical comprehension of key political, social and ecological problems (Hutchings 2007; Chattoo \& Green-Barber 2018; Mann 2016). This also applies to animation (Crawford 2009; Henry 2012) and studies of the features of a humourist's individual style (Havig 2010). Also considered is the evolution of anecdotes and the role of cartoons in media discourse (Feldman 1995; Refaie 2003; Conners 2007; Vasileva 2017; Sienkiewicz 2018). It is interesting that in Chinese culture, humour is generally considered a professional skill expected from the "experts" in the sphere (comedians, showmen) and not from ordinary people (Yue et al. 2016).

Research on purely humorous publications, images and programs specify ideas about the functioning of the modern media, where humour acts as a content-forming and genre-forming factor. This block of work is joined by studies of genre specifics of comic (satirical) journalism in print and digital media (Teplyashina 2007; Ainutdinov 2010; Galliulina 2012; Remizov \& Movchan 2016). The cataloguing and classification of humorous media content allows for the making of assumptions about the gender (Krivoruchko \& Stepanova 2010), age (Krivoruchko 2019) and intellectual (Esralew \& Young 2012) characteristics of the audience.

For the purposes of our analysis, the research direction associated with the use of humour in and about the news is significant. First of all, researchers investigate media that parody news formats, creating fake news and ridiculing particular stereotypes of news presentation in American media (The Onion and Daily Rain) as well as in Russian ones (Fognews, smixer.ru, lapsha.ru, $2 \times 2$ Hobosti). Thus, for instance, frivolous elements in the modality frame of seriousness are published in the parody The Onion.

The Onion is also satirizing genres of contemporary narrative - the newspaper story, along with editorials, infographics, vox populi, letters to the editor, and so forth - by employing the conventions of those genres.

(Brodie 2018: 454).

\footnotetext{
${ }^{1}$ https://telegramfor.me/chan.php?id=meduzaevening
} 
Also, the content of the published "news" may not correspond to reality. These are media texts of an informational and entertaining orientation which can have a referent that is completely fictional (a result of the author's creative activity) or inspired by reality (appealing to a real event) (Panchenko 2017a).

Secondly, scientists are studying so-called comedic journalism which take ironic stances concerning real or fake news, often pronounced by leading comedians or invited celebrities. Examples like the American The Daily Show and Last Week Tonight with John Oliver, the Canadian The Rick Mercer Report, the Italian Striscia la Notizia, and the Russian Evening Urgant and Projectorperishilton are built in this format (Xenos \& Becker 2009; Alonso 2018; Splendore and Domaneschi 2017; Young 2013; Kiseleva 2018). Such a format has been called soft news in the research literature, meaning "entertainment-oriented, quasi-news and information programs" (Baum 2003: 5). The principles of infotainment and soft news are also used for educational purposes, as for example in the United States where investigative journalists and comedians organized "collaborative investigative reporting project about toxic environmental contamination in New Jersey" in order to inform the audience about the environmental danger (Chattoo \& Green-Barber 2018).

It should be noted that the use of humour in news is closely related to political discourse trends concerning the use of humour itself. Forms of this usage are diverse. As an example we can mention a happening that occurred in Israel in 2015, when the news discourse reflected election campaign features which themselves deployed humourous resources for election purposes.

...humour was adopted as a major campaign strategy and senior Israeli politicians took upon themselves the role of comedians in ad clips.

(Mann 2016: 788)

Thirdly, humour is also used in "serious" news. In this case, information about the referent is transmitted by comic means. Thus, the Russian researcher Panchenko N.N. relying on Ruskin's script-based semantic theory of humour, examines the incorporation of the comic in news discourse and stresses the special role of the author in the generation of new meanings:

The ability of a discursive personality to generate a certain type of discourse, that is, through the relation "discursive personality $\rightarrow$ discourse of a certain type" allows us to conclude that the incorporation of comic discourse in news discourse is based on the doubling of discursive personalities (on the principle of "two different types of discourse - two different discursive personalities").

(Panchenko 2017b: 152) ${ }^{2}$

Within the convergence of news and comic discourses into the act of informing, according to the researcher, the news scenario (and the scripts corresponding to it) remains fundamentally informative with the comic element remaining a mere additional. It can be therefore observed that the serious dominates the ridiculous. This means that comical discourse is assimilated by news discourse as an incorporated system and "constitutes only 'discourse in discourse', modifying news discourse but not leading to its transition into another genre" (Panchenko 2017b: 152).

The incorporation of the comic into news discourse is also investigated in particular cases. For example, there are works devoted to the study of comic paratextual elements in news discourse. These elements do not only perform the function of attracting the reader, but also help him/her to interpret the facts and to assess their importance while at the stage of primary acquaintance with the text (Bucaria 2004; Panchenko 2011).

\footnotetext{
${ }^{2}$ Translated from Russian
} 
Acquaintance with the works devoted to humour in news allows us to conditionally distinguish two initial research positions in this scientific discourse, which we will call presumptions: the presumption of news and the presumption of humour. In other words, some research is conducted for the sake of innovation with regards to news genres (Baum 2003; Panchenko 2017b; Brodie 2018; Shilikhina 2019) and others for the sake of understanding humour as a phenomenon as well as for identifying the means of its implementation (Becker 2014; Yue et al. 2016; Mann 2016).

Can we include our research into one or another of the groups mentioned above? Our intention is to remain beyond the limits of both groups or, more precisely, we plan to have our cake and eat it too. In this way we want to demonstrate the appropriateness of humorous approach to today's events (one of the aspects of the presumption of humour) while asserting that news transmission is not damaged thereby (one of the aspects of the presumption of news).

\section{News and humour in Evening Meduza}

In this section, we will try to fulfil the main goal of our research, which is to show the use of humour in an online news media for the formation of a news agenda as well as for promoting and expressing news events in the hypertext newsletter. We will identify several communication speech tools and show the role of paratext in humorous strategies. Before analysing the use of humour in news content, we will offer a subsection (3.1.2.) where we will explain, in the spirit of media linguistics, the basic concepts and terms that formed our methodological basis. To substantiate our choice of empirical material, we will show (at the beginning of this section) the features of the analysed source as a media actively using online channels and humour. The last two attributions of Meduza reveal the contemporaneity and "hipness" of this online news media.

It should be said that Meduza maintains its reputation as an ironic news resource with a witty team using modern means of interactive communication with the reader. In 2019, Evening Meduza readers had the opportunity to participate in an online vote and rate the issue by marking one of two suggested options: "interesting" or "boring". In this choice, the editors propose a specific opposition in which "boring" becomes the antonym of "interesting". The dictionary meaning of these words suggests different oppositions: interesting and uninteresting, fun and boring. Thus, "interesting and fun" can be seen as the professional credo of the Meduza, making this media a valuable object for the study of humour in the mass media.

\subsection{Material and methods of analysis}

\subsubsection{The format of the informing in Meduza}

Meduza.io is a Russian-language aggregator of news and texts, selected manually in contrast to the automatic ranking of "Yandex.News". The project started on October 20th, 2014. Free mobile applications for iOS, Windows Phone and Android became the basis of the media. The daily newsletter Evening Meduza came out starting in March 2015 on workdays - these texts form the empirical material of our study.

To understand the nature of humour used in this media, information about the audience is important. What are the socio-demographic indicators of those towards whom humour is aimed and by whom it can be understood? In 2015, according to media metrics (in particular TNS), Meduza readers were young people, although the editorial staff did not position itself as a youth-oriented media and did not consider standard audience indicators of gender, age. The publisher of Meduza, Ilia Krasilshchik, noted: 
I don't understand how one can orient to the TNS audience. You make the media, which coincides with some internal attitudes and interests of the team. It's not up to the reader. The reader who is interested will come. In our case, the audience 18-34 came, it is the most so-called active part of society and, well, it's excellent.

(adapted from Shmatkova 2015³)

Recent data (March 2019) show that the audience of Meduza has got older and at the same time acquired financial independence and professional solvency: the most active readers of Meduza are highly-paid aged between 35 to 64. The ratio of women in this segment is slightly less prominent (see Figure 1).

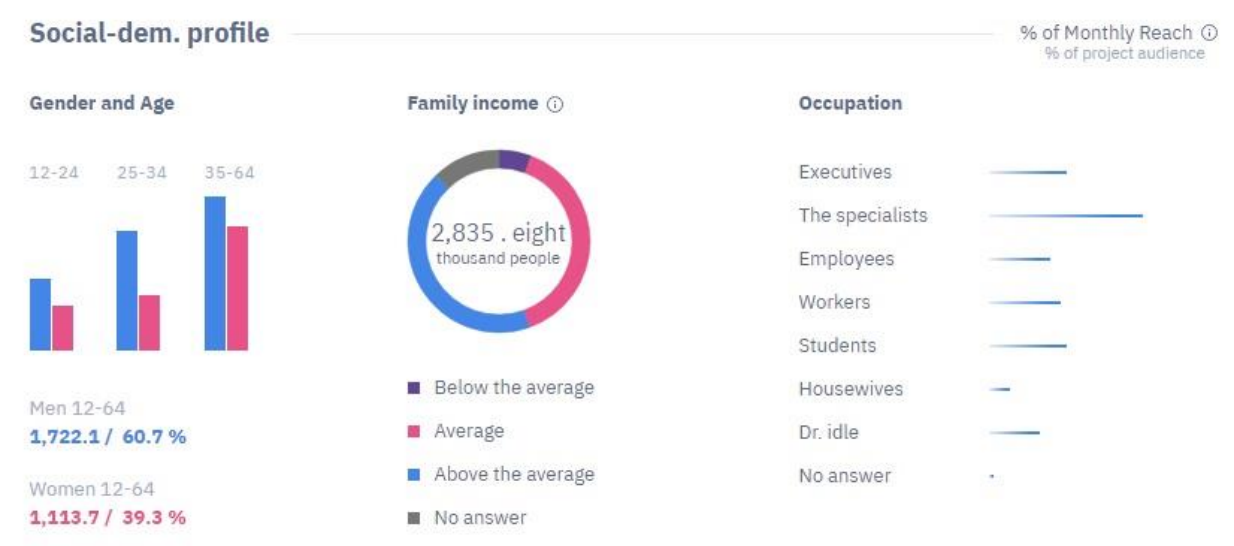

Figure 1. Audience of Meduza. Source: adapted from Mediascope.net

The main idea of the project was formulated by the team from the very beginning. It is expressed by Ivan Kolpakov, who has been the editor-in-chief since the foundation of the project (with minor breaks).

Ivan Kolpakov: "The project has a mantra: "information subsistence minimum". This edition is about what you really need to know. This is a very dense picture of the last hours, collected from the most important news and the best texts in Russian."

(adapted from Surganova 2014 ${ }^{4}$

News is aggregated in texts by the method of deep rewriting. This media does not publish full texts, but always gives accurate quotes, source links and links to related materials that may be of interest to the reader and useful for understanding the news context. Before the project's launch, Galina Timchenko, one of the founders, explained the relationship between aggregated materials and their in-house material.

Galina Timchenko: "We will act flexibly. If there are plenty of high-quality information sources, we will aggregate from them. If it suddenly turns out that other media are writing less, and if stoplists become even longer, we will expand our own content."

(adapted from Surganova 2014 ${ }^{5}$

\footnotetext{
${ }^{3}$ Translated from Russian

${ }^{4}$ Translated from Russian

5 Translated from Russian
} 
The editorial office pays great attention to building the audience's reliance on Meduza's information. For instance, a special evaluative icon near the name of informational sources in the analytical articles title shows the credibility of sources, i.e.: "Source: RBC. - Credible source".

\subsubsection{How does Evening Meduza work?}

The daily newsletter Evening Meduza is delivered (on workdays) to subscribers via email and Telegram messenger. In this format, the principle of "information subsistence minimum" is implemented literally: the entire issue is fitted in the computer screen or smart phone screen.

Evening Meduza (hereinafter EM) is a feed of short and ultrashort (amounting to one sentence) texts (see Figure 2).

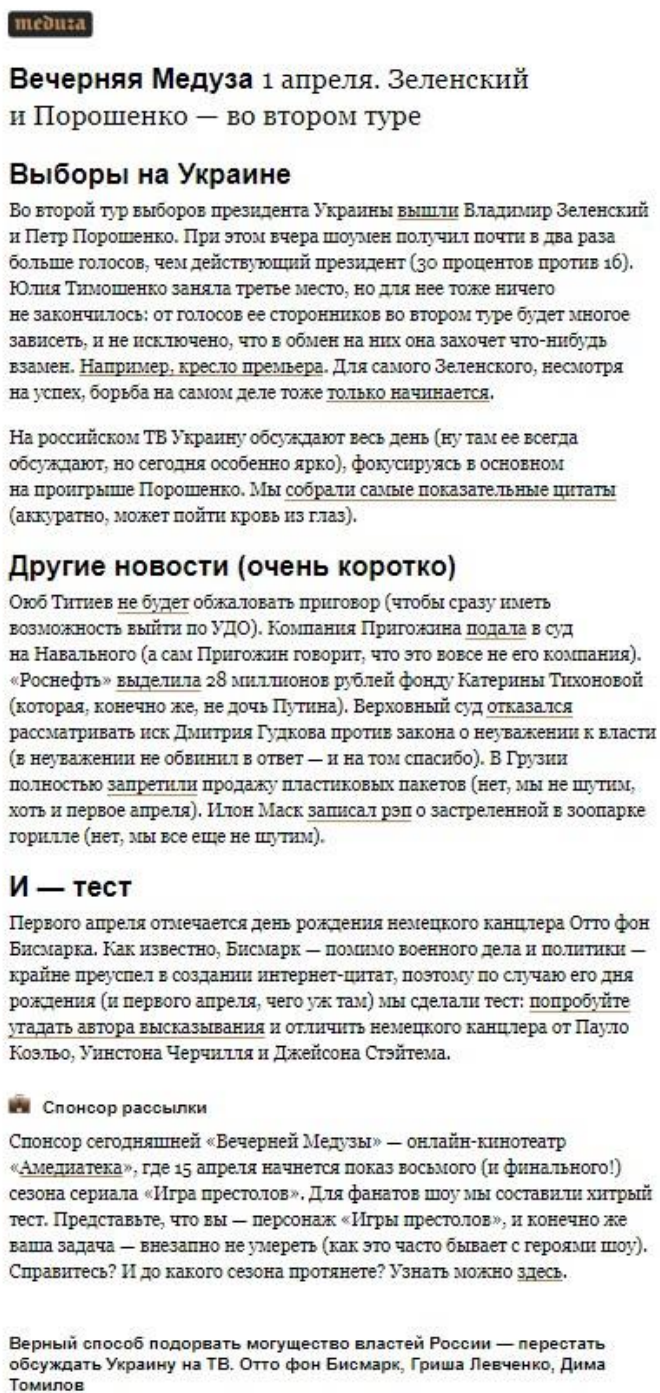

Figure 2. Screenshot of the email with the issue of Evening Meduza [EM. April 1,2019]

As one can see in the image above, news texts are independent blocks with headings and embedded active links (underlined words and phrases) for accessing various media materials: texts, videos, multimedia. 
One issue usually contains five or six text blocks. One of the blocks, usually the final one, has either an informative and entertaining function (test concerning the topic of the day) or contains a sponsored text that has an advertising function. Four or five blocks are the news messages themselves. The authors of all these messages are the Meduza staff reporters whose names are at the end of each issue. We can say that the whole issue is one cohesive journalistic piece coloured with humour. This constitutes the most important difference between EM and more typical news aggregators.

In the screenshot we show the April 1st issue, released on April Fool's Day, known as the "day of laughter" and celebrated in Russia and other countries. This is an unofficial folk holiday (Subbotina 2015) embodying and continuing carnival culture (Bakhtin 1990 [1965]: 15). On this day there is a custom to joke, make pranks and to use one's wits. However, on this day, EM doesn't take part in the common "ritual laughter" (M. M. Bakhtin's term) and makes an extremely short issue. Thus, we can show in the image the entire issue as a polycode hypertext while preserving the features of its layout.

The issue shown in the screenshot includes one news text message ("Elections in Ukraine") and its packaging in the format of a "headlines list" collected under the heading "Other news (very short)". The issue contains two entertaining blocks: a funny test to check one's knowledge of famous quotes as well as a sponsored text (which also happens to be a test, but dedicated to the popular TV series Game of Thrones).

The small amount of content (about 300 words or 2000 characters) in this issue has, however, clear paratextual elements that form a logical and emotional perception of the entire issue. In the email, the subject is indicated (Who is Elon Musk rapping about?) and its body contains the output of the issue - the name of the media, the date, the issue's theme. Usually the issue theme does not duplicate the letter's subject (Evening Meduza. April 1. Zelensky and Poroshenko in the second round). At the end of the issue, the authors names are published with a mandatory, often humorous, adage: The best way to undermine the power of the Russian authorities is to stop talking about Ukraine on TV. Otto von Bismarck, Grisha Levchenko and Dima Tomilov. Looking ahead, we want to note that even at the level of paratext, the authors' basic attitude is obvious: the authors show their hope that the reader has a sense of humour, is educated and appreciates both irony and self-irony. Thus, in the authors' signature in the example above, the journalists put themselves on a par with the character from the quiz - in this case, Otto von Bismarck, whose quotations were used in the quiz. In this way, they give to their own adage the status of an important statement worthy of being included in a quote book.

\subsubsection{Methodological basis and methods of analysis}

The methodological assertions we apply to analysing humour in the media texts of EM are as follows.

1. Informing through professional speech activities in the media solves the problem of actualizing certain aspects of the news event (Duskaeva 2014) - in the material we work with, this is marked with humour.

2. For understanding humour, it is necessary to describe the communicative-semantic characteristics of the text (or hypertext) in a more or less comprehensive way (Vasileva \& Redkina 2019) while bearing in mind that the text is the expression of the communicative situation containing a humorous component.

3. The most important principle is the main tenet of medialinguistic analysis: the systematic approach (Duskaeva 2015). It consists of taking into account the interconnectedness of text components, one that leads to the emergence of new, integrative text properties which are not inherent to the individual elements. 
Two scientific sources give us the basic concepts and terms necessary for our analysis. They are partly derived from works on medialinguistics - their content is clarified and defined in the special dictionary Medialingvistika $v$ terminah $i$ ponyatiyah: slovar'-spravochnik ('Medialinguistics in terms and concepts: a dictionary-reference') (Duskaeva et al. 2018). It is also partially derived from the dynamic linguistics of Murzin (Murzin \& Shtern 1991) and the cognitive semantics of Chafe (1976). The first group of concepts include media text, hypermedia text, polycodeness and paratext. Here we note only the most important features of these concepts for our approach. Afterwards we will elaborate on compression, packaging, contrast and empathy in more detail.

Media text, as a central subject of medialinguistics, is understood as a social communicative action carried out in the context of a particular type of speech activity. Any media product intended for a wide audience can be considered a media text.

The study of media texts in a so-called activity-oriented way means analysing them in close connection with real circumstances. In this regard, media texts are classified in medialinguistics by taking into account factors in their creation: 1 ) type of professional speech activity (journalism, advertising, public relations) 2) technical elements, channel, time, duration, place in the structure of the issue, in the news feed or program, broadcasting methods, 3) target orientation, 4) communicative status of the author and addressee, 5) norms of professional, ethical and legal regulation in the chosen field.

(Duskaeva et al. 2018: $74^{6}$ )

The boundaries of the media text are as much a debatable scientific problem as the boundaries of traditional texts (Vasileva \& Salimovsky 2010). In our analysis, we can consider EM issues as a media text, as a polycode association (unit) and as organized paratextually. At the same time, we can consider the separated text blocks inside the issue as independent media texts or, more precisely, hypermedia texts (Duskaeva et al. 2018: 359-360), referring to all media texts "hidden" behind a hyperlink. At the same time, the whole issue is essentially a hypermedia text, as it is intended for reading according to conditions and possibilities of the Internet communication (Bolter 1991).

The next concept is polycodeness which we understand as polycodeness as an ontological feature of the media text, media speech in general. Polycodeness is an act of integration of natural language with the components of other semiotic systems (pictures, sounds etc.) (Duskaeva et al. 2018: 88). It is multi-layered: the verbal and visual structural elements of media text are also polycode entities.

Natural language is represented in the media text in a certain visual embodiment (we can talk about a kind of "infographicness" of the verbalics), and the image of non-verbal components includes signs of different nature (iconic signs, symbols, indices).

(Vasileva \& Duskaeva 2016: 3987)

The polycode media text acts as an integral structural, semantic and functional whole as it is aimed at making a complex impression on the addressee (Voroshilova 2006) by the means of different semiotic systems. Distinctive genre forms of humour can be built while elements of different semiotics systems interact.

The paratext elements in our analysis are, firstly, the headings and everything that relates to this structural element of the media text (the heading, the subheading, the total title, rubric, author's signature), and secondly, the paratextual elements are visual components having permanent symbolic value in the issue of (icons, location, fonts). Proposed by the French

${ }^{6}$ Translated from Russian
${ }^{7}$ Translated from Russian

Open-access journal| www.europeanjournalofhumour.org 
researcher Genette (1997) in relation to fiction, in digital reality paratext becomes a special form of interaction with the audience:

...digital media allow for the proliferation of paratextuality because we can click, click, click, and get through way more than we can get through in physical space. They allow for a heightened ubiquity and everydayness of all sorts of texts.

(Brookey \& Gray 2017: 104)

Media linguistics analysis is an interdisciplinary study. It is constantly updated by the concepts and categories from related fields concerning speech activity. One such concept worth mentioning here is compression. It reflects the essence rewriting (as a textual activity) in its positive, creative sense, when a journalist faces the task of creating short news reports based on texts from different sources. In general, rewriting (the creation of a text based on several ready-made texts covering the same case) is a highly respected skill in the modern media conditions. Language gives the possibility for infinite variations of the same content in different shapes. Then content itself (this is important) is transformed under the influence of form modification.

Compression, coagulation, compaction, condensation, reduction - these and other terms are used to refer to compression. We will not dwell here on the terminological diversity which reflects the profound differences in the linguistic interpretation of the compression phenomenon. We will merely state that in linguistic works, compression is understood syntactically (coagulated components in the structure of sentences) (Haritonova 2012), stylistically (for example, in advertising texts) (Shokina 2008) and word-formative (syntacticderivative correlation, univerbation, etc.) (Kosova \& Sun Miao 2015). It is important for us that the compression phenomenon is always understood as the basic ability of a language to include a large amount of information (including implicitly) in a small amount of text. This is achieved, as is known, by transforming the utterance at the level of the sentence. At the level of the text, we can talk about the transformation (reduction of the number of textual units) of some source text into a text message intended for direct perception in a particular communicative situation.

Compression is not only about structural transformations. The process, some preceding text indicators, connective operation, the result of feature ascribing to a given object are compressed to the nomination.

(Murzin \& Shtern 1991: 478)

Firstly, as noted by Murzin, "compression as the coagulation of the text can take different forms" (Murzin \& Shtern 1991: 34). Secondly, "compression of the text is one of the ways of the most complete transfer of its integrity" (Murzin \& Shtern 1991: 73). The last remark draws attention to the preservation of the compressed text's content: although compression involves losing parts of the content, the overall sense of the text must be preserved while the reader unpackages it.

The unpackaging of text structures (blocks or hypermedia texts in the newsletter's structure) is like unwrapping candy wrappers. There is something expected inside the wrapper, although what exactly may remain ambiguous. Unlike a real wrapper, however, deploying a text could lead to a humorous effect. But a sudden surprise is not enough for understanding the humour built into news-wrappers. In search of a methodologically useful concept, we turned to the term "packaging", proposed by W. Chafe in 1976 and developed in the field of cognitive science. Chafe was interested in "the various statuses that a name could have" (Chafe 1967:

\footnotetext{
${ }^{8}$ Translated from Russian
} 
278). Among them, we are interested in contrast and empathy. The contrast, according to W. Chafe, expresses the fact that some unit in focus is more suitable to express the speaker's desired content than any other. The status of empathy, in our opinion, is interesting for revealing the mechanisms of humour in mass media communication.

The core of this status [empathy] is that a person has the ability to imagine himself looking at the world through the eyes of another person, or from his point of view, and that this ability affects the use of language.

(Chafe 1976: $313^{9}$ )

The actionable aspect of speech is expressed in the term "packaging" in the paper of W. Chafe and in papers of his followers (McCoy 2003; Krifka 2008). This means that a change in the focus of contrast and an empathic turn (a change in the direction of the packaging's unwrapping) indicate a change in the perception of specific entities and events. We will use the concept of packaging to define the format of compressed texts in EM newsletters, and we will use the concepts of the focus of contrast and the position of empathy as humorous tools.

The most important method in the study of such a phenomenon as humour is introspection (Chafe 2008), used in non-instrumental studies of language processes. Prior to any analysis, humour needs to be identified, for instance by asking questions such as: Why is something funny? How was this funny action done? The authors of this paper undertake the responsibility to decide whether a particular issue or a single text are humorous as being familiar to national cultural specifics of humour in Russian-language media. It should be noted, however, that the recognition of Meduza as a media outlet that actively uses humour (positively or negatively evaluated) is taken as a given by all readers. For the study of humour in the media we chose the media that has provided a wealth of material for analysis: in the two-month's worth of EM issues we found, news pieces using jokes were identified in each issue.

\subsection{Strategic tools of humour}

Without claiming to be comprehensive in the analysis, we consider humorous tools in EM via three analysis vectors at this stage of research. These vectors are: empathy in packaging texts, focus of contrast on paratextual interconnection and news visualization - which are the structural blocks of the issue. It is clear that the proposed typology is conditional, because a humorous impression is created by the simultaneous participation of different properties of speech and visual material in each structural component of the issue - in other words, a humorous impression is created by a system of 'humourogenic' properties. We tried to find properties which are specific for every structural block containing humorous tools in the newsletters.

\subsubsection{Playing empathy}

The specificity of contemporary media work entails the need to maintain the emotional tension of communication with the recipient and control the preservation of high density of information flow. This is what professional journalists say.

Broadcasting fashion is changing rapidly; the degree of emotionality rises very quickly. More effort is needed, more emotional, informational, visual intensity is required. Everything became more intensive.

\footnotetext{
${ }^{9}$ Translated from Russian
} 
The intensity, the tension, the saturation of the media - all these signs of tension in communication should somehow be provided along with some form of release for the reader, otherwise he will avoid such communication (Grice 1975). Since EM has high density of informing (each short issue provides an informational glance at the whole day), the release of the reader's tension is necessary and this release should exist at the level of the whole text. We find this release in empathy. This is a connection built with the audience when the text presents a view of the event "from behind the reader" (according to Chafe). Each message in EM is a compressed packaging of recent news events that requires the reader to take action while the text is unfolded. Empathy is intended to make the process of unpacking the news, on the one hand, fascinating, while on the other satisfying the audience's intellectual needs through hidden information found in humorous referents.

The empathic turn is carried out by the change of narrative perspectives in the textpackagings. Let's show this through the example of a specific piece of news related to the socalled "Kokorin and Mamayev Case" about a fight between famous football players and officials. The official Denis Pak was hit with a chair and a court sentenced the players to prison terms - the event caused a wave of discussion and gave rise to many humorous reactions and memes. EM regularly published news about this criminal case (hereinafter all examples from an issue of Evening Meduza are supplied with a note in square brackets: [EM. Date of issue.] English translations of text extracts are made by the authors of the article).

\begin{abstract}
Stulu - smertnyj prigovor. Pomimo prigovora futbolistam, sud takzhe postanovil unichtozhit' stul, kotorym Kokorin udaril chinovnika Denisa Paka. Socseti nedoumevayut i grustno shutyat. Na samom dele unichtozhenie orudiya prestupleniya - standartnaya praktika, vot tol'ko voobshche neyasno, tot li eto stul: vo vremya sledstvennyh dejstvij iz «Kofemanii» prosto zabrali pervyj popavshijsya.

'For the chair: a death sentence. In addition to the players' sentences, the court also decided to destroy the chair Kokorin used to hit official Denis Pak. Social media is confused and makes sad jokes. In fact, the destruction of the murder weapon is a standard practice - it's just not clear whether this is the same chair. The first available chair was taken away from "Coffee mania" during the investigation'.
\end{abstract}

[EM. May 8, 2019]

The news headline uses ellipses with prosopopoeia: the piece of furniture is portrayed as a convicted criminal. The news aims to meet the needs of two different types of readers. The first usually unwraps text-packagings for the sake of information (let's call this type "serious"). The second ones are those who look, firstly, for an ironic object ("laughers"). We propose this conditional separation for analysis purposes: it is obvious that one real reader can act in both roles.

The intriguing headline "For the chair: a death sentence" is "unpacked". It reveals its content through four shifts of narrative perspectives that shift the focus of contrast and are revealed in the following sections of the news.

1) The introduction of the true referent takes place in the first sentence of the news ("the players' sentence") immediately after the title. It tells about the case of the players Kokorin and Mamayev, and EM's empathy is on the "serious" side.

2) Message-assessment ("social media is confused and makes sad jokes") follows. The assessing party is the online community users, which are designated metonymically as "Social media." EM shares the position of social media: together with the hypothetical

10 Translated from Russian 
reader, it shows irony about the situation, and invites them to click the link to the summary of humorous comments about the "execution" of the chair. The degree of absurdity indicated early in the heading ("For the chair: a death sentence") increases, and all these speech actions together cause a humorous reaction. This shows EM empathy moved on the side of the "laughers".

3) The phrase "In fact" makes a sharp turn to "serious" informing. The narrator, as if suddenly shedding the smile from their face, reports on the normativity of the chair's destruction (as evidence) in the course of the investigation using official and business vocabulary and tone. EM empathy is now on the side of "serious".

4) With "It's just not clear" the narrative perspective changes again. Conversational constructions and the excretory-restrictive particle "it's just" (such particles (Krifka 2008) usually emphasize the focus of contrast) change the tone to show an ironic point of view on the situation. A hyperlink offers to go to Meduza's main site, where all the juicy details of Kokorin and Mamayev's case are described, as well as a mocking set of user comments. The empathy of EM moves again to the side of the "laughers".

It should be noted that the hyperlinks to the main site's news pieces are embedded in the text-packaging involving verbs of speech, signaling laughter ("make sad jokes") and anchored in the comment about the peculiarities of investigative procedures ("The first available chair was taken away" - this comment received a humorous tone in the text within the context of a serious message). Thus, intertextual threads of laughter and irony connect the compressed textpackaging with other texts devoted to the same topic and aimed at its further ridicule. On the one hand, the authors of EM perform normative professional speech actions to inform - they report who, what and when something happened, which seems to be unable to prompt readers to click through the links to the main site. However, narrative turns, creating dissonance, providing the contrast of "serious" and "laughing" speech fragments, which sharply change the script (according to V. Raskin) and excite the reader's interest.

It is important that the referential field and the humorous assessment field of the "wrapper" are simultaneously expanded by clicking the link. The humorous assessment field can be expanded by means of such stylistic device like the hint which, in its turn, evokes new contrasts. The hint requires the reader to make an intellectual effort, since it contains implicatures of relevant topics of media discourse in general. Hypertext threads can link news with publications about such events, which have already become part of the "informing wave of discourse" (Duskaeva et al. 2018: 223) or even were assessed like in the following example.

Lajfhak (dlya Kokorina i Mamaeva). Kak izbit' cheloveka, esli ty futbolist, chtoby potom ne prishlos' polgoda sidet' v SIZO? Ochen' prosto - pered izbieniem dostatochno ubedit'sya, chto ty b'esh' ne chinovnika. Futbolist «Spartaka» Ayaz Guliev ustroil v centre Moskvy draku s prohozhim iz-za togo, chto tot pomeshal ego "mersedesu" spokojno proekhat' na krasnyj svet. Prohozhij okazalsya prostym grazhdaninom SShA, poetomu Guliev otdelalsya nebol'shim administrativnym shtrafom i oficial'nymi izvineniyami.

'Life hack (for Kokorin and Mamayev). How to hit a person, if you are a football player, without going to jail for six months? It is very simple - before hitting, just be sure it's not at an official. "Spartak" football player Ayaz Guliyev staged a fight in the center of Moscow with a passer-by due to the fact that he prevented his "Mercedes" from driving quietly through a red light. The passer-by turned out to be a simple US citizen, so Guliyev got off with a small administrative fine and an official apology'.

[EM. April 12, 2019]

The text (which has a genre definition of 'life hack') is based on the phatic genre "advice". However, this text is not advice at all. A para-ethologism is used here - this is a violation of 
behavioural norms ("how to hit a person") to show that "advice"" should be understood in the opposite sense. Funny recommendations about hitting serve as a play on empathy and provides a shift in the focus of contrast: numerous jokes about the "case of Kokorin and Mamayev" that exist on the Internet emerged. Question-and-answer forms of presentation, conversational elements ("got off with"), irony ("driving quietly through a red light") form an illocution of criticism, a condemnation of existing judicial practice: here is a hint about the asymmetry of the application of laws in relation to officials and ordinary citizens. At the same time, the unfolding of the text from the fragment "got off with a small administrative fine" which redirects the reader to the main site, is sustained in a serious tone and has no references to the case of Kokorin and Mamayev.

Thus, the text-packaging, organized as a tense, compressed text, are unfolded by the recipient who is not only in search for new relevant information, but also in decoding humorous meanings. The relieving of intellectual and emotional tension is achieved by changing the narrative perspectives by shifting the focus of contrast within one item of news. This principle expands the referential field of the message, and also allows the demonstration of empathy to readers who have different presuppositional expectations - which also serves to meet the readers' interest. The system of hints and references to implicatures of news discourse helps EM-authors to enter additional illocutionary vectors in informing. The addressee "reads" additional meanings via the humorous tone of pseudo advice, pseudo puzzles and pseudo quizzes, which all correspond to rhetorical questions, the answer to which is obvious to EM audience members (who are assumed to be able to think critically).

\subsubsection{The focuses of humour in paratext}

The paratext of EM is made up of various, heterogeneous elements. These are the speech components with their graphic features (issue themes, headings, author's signatures) and images (photos, drawings, "pictures") which interact with each other across the space of the issue.

We will begin the analysis of paratextual tools of humour in EM with an author's signature that is traditionally included in the heading framework. In traditional media, this component is not coded with the importance of, say, a heading, but in EM the author's signature has a bright, individualized character. The signature is at the end of the issue and usually contains the names of two journalists. But it should be noted that traditional Russian shortened names are given, like Grisha, Dima, Vova instead of the more formal (and professional sphere) Grigory, Dmitry, Vladimir. Such naming conventions make communication more familiar, informal and even humorous. A specific component of the signature, which is not usually found in media, is prepositive speech construction, a kind of postscript-attribution. For example: "Podpisyvajtes' na nash telegram-kanal @ meduzaevening, raz uzh on ne zablokirovan. Grisha Levchenko, Vova Cybul'skij" 'Subscribe to our telegram channel @meduzaevening, since it is not blocked. Grisha Levchenko, Vova Tsibulsky' [07.05.2019]; "Horosho, chto Kim Chen Yn ne zastavlyaet ohrannikov bezhat' za bronepoezdom! Grisha Levchenko, Kostya Benyumov" 'It's good that Kim Jong Un doesn't make the guards run after the armored train! Grisha Levchenko, Kostya Benyumov' [24.04.2019].

The addition after signature has the manner of an adage, an ironic comment that highlights some of the news in the issue and often forces the addressee to read the issue again to understand the connection. As a rule, coupling an adage with news content does not establish a direct logical connection but forms a contrastive focus, which is perceived by the reader as an ironic assessment. And what is being assessed? This only becomes clear only when the reader analyses the issue as a whole. Let's show it on the example of an issue's heading framework. 
<E-mail subject > May 23. Kak zhivut v Rossii bezhency, priekhavshie na ChM-2018 <2018 FIFA World Cup> pod vidom fanatov? 'How do refugees who came to the 2018 World Cup under the guise of fans live in Russia?'

$<$ Heading of the issue> Vechernyaya Meduza 23 maya. Tolerantnye rossiyane, medlennyj SK $<$ Investigative Committee> $i$ dolgozhdannyj "Terminator" 'Evening Meduza on May 23. Tolerant Russians, slow IC and the long-awaited "Terminator"'

<Signature>S Kemeronom "Terminator" prosto ne mozhet ne byt' krutym! Grisha Levchenko, Dima Tomilov 'With Cameron "Terminator" just can't help but be cool! Grisha Levchenko, Dima Tomilov'.

[EM. May 23, 2019]

In this issue, there are 6 newspieces on different topics: (1) growth of tolerance to homosexuals, according to the "Levada Center"; (2) a gender scandal at a school in Perm; (3) new data of the Fund of Struggle against Corruption concerning Medinsky's income; (4) the long-awaited verification of the Investigative Committee in the complaint of a Chechen Republic resident; (5) announcement of Meduza's exclusive material on refugees; (6) the announcement of the video about the premiere of "Terminator: Dark Fate". As can be seen in the example, the adage in the signature focusing on the film news seems without irony: the confidence that the film will be good is expressed in the commentary. However, the very choice of film news for inclusion in the headline from a list of serious and important ones is an ironic assessment of the agenda as a whole. The authors inform the reader that all events in the world and the fate of people fade before the latest Terminator movie.

The authors do not always comment on the news or the topic of the day in the signature adages, although they have designated this news as "main news" in the subheading by themselves. However, these adages always give a humorous tone to the entire issue, even as the subheadings (when read in isolation) contain statements or expressively neutral directives: "Ne boimsya my volka i sovu!" "We are afraid neither of the wolf nor the owl!"' [EM. April 29, 2019], "Pozvonite roditelyam - osobenno esli oni u vas nemolodye" 'Call your parents especially if they are elderly' [EM. May 14, 2019]. These authors' signatures are humorous, but in order to be in on the joke, readers need to have been paying attention to the issue as a whole, and to how the newspieces are interconnected.

In the phrase "We are afraid neither of the wolf nor the owl!", readers aged 35-40 may recognize a line from the soundtrack to the famous Soviet film The Diamond Hand. The news release about the 50th anniversary of the film is wrapped in a packaging "test", where the reader is invited to check their knowledge of the film soundtrack's lyrics. Thus, it would be possible to note the playful nature of the signature and in this way limit the humorous meaning of the quote usage. However, there is another paratextual link in the issue that forms a contrastive focus. This is the link between the theme of the issue and the comment in the signature. In the name of the topic issue another line from the same soundtrack is used; its refrain "A nam vse ravno" 'And we don't care'. In the past, this phrase immediately entered the pantheon of movie quotes and was often used (and still used today) in the puns of media headlines. In modern Internet communication, the phrase is used as a meme, expressing either desperate fearlessness in a difficult situation, desperate stupidity or even bravado (for example, it is used under a video where a car enters a large puddle in hopes of driving over it, but sinks up to the roof). In the analysed issue, the announced news is presented between the two lines of song lyrics: "And we don't care" (song line is used as an issue topic) - "Rossiya menyaet posla, Genprokuratura toropitsya s prigovorom" 'Russia changes the Ambassador, the Prosecutor General's office in a hurry with the sentence' (the announced news is in the issue heading) - ""We are afraid neither of the wolf nor the owl!" Grisha Levchenko, Vova Tsibulsky" (song line is used along with signature). In this case the contrastive focus is formed by a quote frame, it creates a humorous effect already in the paratext. 
Font highlighting, in particular subheading highlighting, helps readers see the individual elements of the paratext as part of the whole. The heading is known to be the strongest position in the media text; the headings of EM news messages (packaging news) are the subheadings of hypermedia texts (of the issue). Subheadings can be classic headlines and compress the main content of the news (Lashchuk 2004), but they can also present the news in a way that matches the worldview of the author. Thus, not only an active link inside the package (as shown in 3.2.1.), but also contextual links arising between the subheadings of the issue can change the perspective of the news narrative.

In these connections there is a humorous intonation of varying degrees of intensity - from the humorous to sarcastic. For example, in the short issue of April 10 there are only three news blocks; here are their subheadings: "Chernye dyry sushchestvuyut!" 'Black holes exist!' "Zemnye novosti (korotko)" 'Earth news (shortly) ' - "Tekst dnya" 'Text of the day'. The news about the evidence for the existence of black holes dominates the issue, and is supported by the postscript in the signature and by its design: "Pyat'desyat. Millionov. Svetovyh. Let. Umu nepostizhimo. Grisha Levchenko, Dima Tomilov" 'Fifty. Million. Light-years. Mind-boggling. Grisha Levchenko, Dima Tomilov'. In the author's signature, each word is separated by a dot: the intonation of extreme shock is provided with punctuation marks. It should be noted that in such punctuation we see not a stylistic-syntactic technique (called parcellation or detachment), but an author's use of a graphic means (dot) to convey the intonation of chanting and listing individual words with an logical accent on each. It is clear that the shocked authors do not have the strength to talk about the temporal earthly news, so they give them in the format of a list of headlines. The demonstration of the psychological state, and the authors' emotional openness, creates a humorous tone for the whole issue. In the context of this humorous tone, the news that the first President of post-Communist Romania was charged with the deaths of hundreds of people during the 1989 revolution (the subheading "Tekst dnya" 'Text of the day') does not actualize the theme of the tragedy but presents it as an event that belongs to history and therefore does not cause strong emotions.

The ironic interconnection of an issue's subheadings is one of the constant humorous tools in the paratext: "V Rossii deneg vse men'she..." 'There is less and less money in Russia... ' "...zato voruyut ih vse bol'she" '...but they steal them more' [EM. April 9, 2019]; "Chto mogut zablokirovat', no poka ne hotyat" 'What they can block, but do not want to yet' - "Chto hotyat zablokirovat', no poka ne mogut" 'What they want to block, but they cannot yet' [EM. April 5, 2019]; "Kogda v goszakupki popadayut diagnozy" "When diagnoses get into public procurement' - "Kogda sama goszakupka - uzhe diagnoz" 'When the public procurement itself is already a diagnosis' [EM. April 3, 2019]. Such subheadings create a comic contrast, forming its focus on individual parts of the referential content, and a reader asks a question: who steals money? what exactly is being blocked? who benefits from public procurement? As there are no direct answers to the questions of this hypothetical reader, he or she can still, by unfolding the text-packaging, look for the answers in materials and podcasts. This is because a reader have already been prepared to perceive the day's news as interconnected.

\subsubsection{Visualizing news in pictures}

Some news items in EM issues are accompanied by visually oriented components like photos and drawings. As a rule, these visualizations are purely illustrative: the first photo of the newborn son of Prince Harry and Meghan Markle, a photo of the "black hole" and anything of this kind.

There is, however, a block with a mandatory humorous component. This block is called "I - kartinka" 'And - picture'. The block is designed as a permanent but irregular heading; its place is at the end of the issue and such a position is accepted for entertainment rubrics. The 
heading of this block features non-standard punctuation: a dash after the conjunction "and" (this conjunction is often used in EM headings as a unifying component) and before the noun "picture". In a series of headlines that also begin with the conjunction "and", the name of this block forms the focus contrast. This focus of contrast demonstrates a change in the usual rule for the regular reader: the next news will be told with the help of a new semiotic code, a visual one. Here one needs to pay attention to the shape of the pictures (see Figure 3; the analysis of the text in the picture will be given below), which resembles a humorous Internet genre, the demotivator. This is a black rectangular frame with an inscription in white letters on a black background frame.

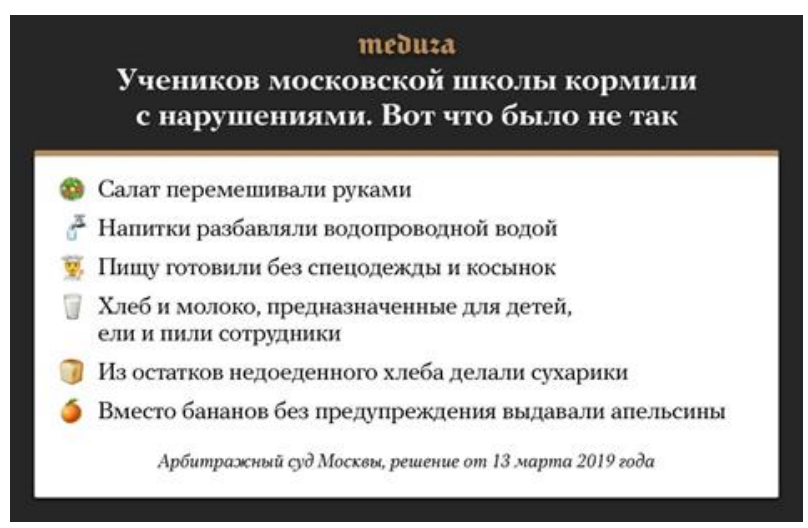

Figure 3. "Picture" to news [EM. April 4, 2019]

Demotivators appeared in the late 1990s as a parody of motivational office posters (mostly American), which encouraged employees to work harder and achieve their goals, like a type of social advertising.

Demotivators are mostly cynic or ironic...They spread very easily \& quickly as commentaries \& responses to the hot media subjects.

(Brzozowska 2013: 124)

Researchers note that a demotivator as a polycode text is based on the paradox between the image and the inscriptions (Golikov \& Kalashnikova 2010; Bugaeva 2011; Rabkina \& Kameneva 2013). In our case, we can say that this paradox arises on the basis of the humorous dissonance, which was described at the time by Raskin and Attardo and arising between the text and - oddly enough - text.

Images in EM are decorated in the style of the demotivator graphics: in the role of the heading is the text in white letters on a black frame at the top of the picture, and the text inside the frame plays the role of the image. The ironic meaning of the news in the "And - picture" block is formed at the junction of the upper inscription and the text inside the frame. Such pictures in EM are another form of game with the reader who is knowledgeable about Internet communication. These pictures are offered "à la demotivators" (similar to demotivators) to the reader. The reader knows how to read and decode these EM-pictures from the experience of having seen true demotivators.

In our example, the picture is used for the following news.

Arbitrazhnyj sud Moskvy udovletvoril isk odnoj iz shkol k kompanii «Moskovskij shkol'nik», zanimayushchejsya postavkami pitaniya v uchebnye zavedeniya. Kompaniya (kotoruyu Naval'nyj svyazyvaet s Prigozhinym, kotoryj, v svoyu ochered', ot nee otkreshchivaetsya) zaplatit poltora milliona rublej za celuyu seriyu vyyavlennyh sudom narushenij. 


\begin{abstract}
'The arbitration court of Moscow upheld the claim of one of the schools toward the company "Moscow schoolboy" engaged in the supply of food to educational institutions. The company (which Navalny associates with Prigozhin, who, in turn, denies it) will pay half a million rubles for a series of violations identified by the court'.
\end{abstract}

[EM. April 4, 2019]

There is a list of violations noted by the court in the picture frame, and there is inscription over the frame on a black background: "Uchenikov moskovskoj shkoly kormili s narusheniyami. Vot chto bylo ne tak" 'Pupils of the Moscow school were fed with violations. That's what was wrong'. After reading about the violations, the reader discovers their insignificance, but a significant fine was imposed. These violations are: employees ate bread and drank milk intended for children; they made crackers from the remains of half-eaten bread; they gave out oranges instead of bananas without giving appropriate notice. The court's decision is questionable: most likely the real circumstances of the company's activities are hidden from the public. The list of violations, decorated with a list of cute icons, looks like a mockery of the serious problem of school meals. This case became the basis of a big scandal in Moscow schools. Thus the author of this mockery is specified in the picture. This is the Arbitration Court of Moscow, as the listed points are taken directly from the judicial document.

Why is this news presented as a picture? In our opinion, the picture, made by journalists compresses a news event and reveals a new side. That means that the focus of the news moves to the connection between the à la demotivator elements (inscription and text in the frame). Now this is not a message that the court decided to punish the perpetrators, but that the Moscow Schoolboy company managed to avoid legal charges, as the violations imputed here cause only an ironic smile, and the court's decision is not credible.

Thus, the picture accompanying the news becomes a tool for critical ridicule of the actions of all organizations listed in the news: both the company and the court.

Here is another example of the use of images in the issue, which is almost entirely devoted to an important topic of the law concerning isolating the Russian Internet (see Figure 4). News text: "Esli Rossiya izoliruet ot interneta sama sebya, dlya samoj strany eto stanet katastrofoj, a vot za ee predelami etogo, skoree vsego, pochti nikto ne zametit. Vot pochemu" 'If Russia isolates itself from the Internet, it will be a disaster. In the outside world, most likely, almost no one will notice. That's why'.

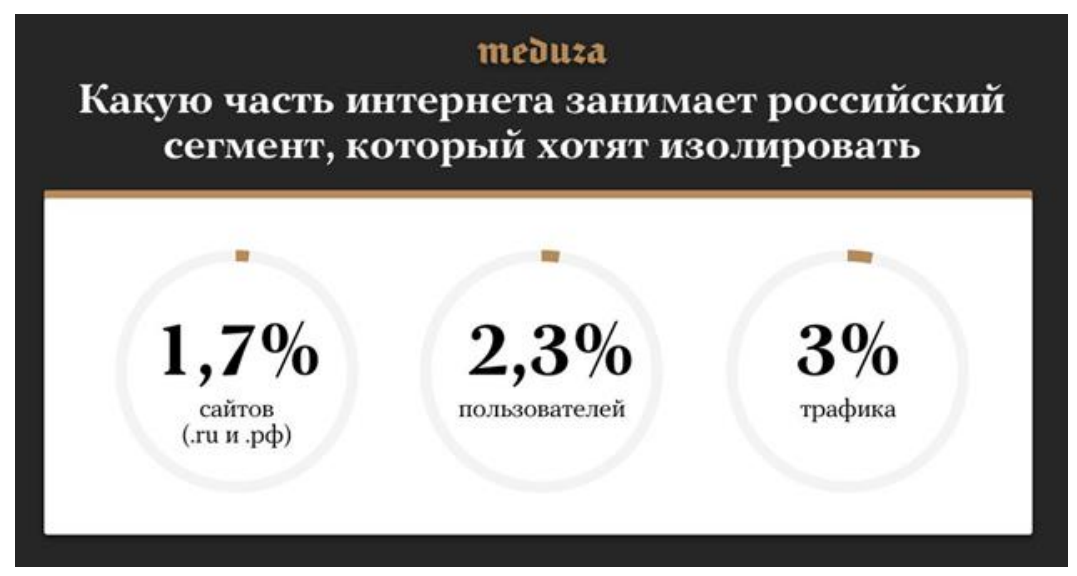

Figure 4. The news about the isolation of the Russian Internet [EM. April 16, 2019]

The inscription in the picture: "Kakuyu chast' $v$ internete zanimaet rossijskij segment, kotoryj hotyat izolirovat'" 'How much of the Internet does the Russian segment, the one they want to isolate, take up'. There is the data in the frame, indicating that the Russian Internet is very small 
(1.7\% of sites have the domain .ru and .pp - Russian users make up $2.3 \%$ of the global share, and traffic amounts to 3\%). The figures show that what they want to isolate is almost nonexistent. As you can see, the focus of the news is shifted to the part of the event that raises doubts and therefore becomes the object of criticism. This creates a paradox à la demotivator with the ironic content required for its prototype.

The block "And - picture" is rare in EM; there are only about $20 \%$ of issues with this block in our card index. But the presence of such a component advantageously enlivens the genre forms of EM texts and increases the proportion of blocks created with use of humour. The latter gives the whole issue a humorous tone, and this tone becomes a normal, familiar way to tell the news for the reader.

\section{Conclusion}

A systematic, medialinguistics glance at the use of humour in EM allows us to draw a number of specific conclusions. The empirical material of our study reveals the intersection of the presumption of news and the presumption of humour. This is due to two reasons: 1) Evening Meduza observes the conventions of news reporting while offering a humorous look at the events of the day; 2) the humorous elements in EM can be attributed to the process of developing a primary assessment of what happened during the day, and humour serves as a means of coordinating the semantic positions of the author and the reader, and thus their mutual empathy. Thus, the news informing in EM (one of the aspects of the presumption of news) in a humorous frame (one of the aspects of the presumption of humour) stimulates the cognitive efforts of the audience, which is offered daily to form a critical view. We believe that this is a special case, which can later become the basis for the analysis of the work of news media that systematize the news of the day.

Humorous and non-humorous texts located in the limited space of the issue, form a binary opposition in which one component is always marked while the other one is not. Marking is a question of a point of view. Texts with a humorous component (special and rare in news discourse) seemingly should be considered "marked with humour", marked a member of the opposition. But in EM issues, texts without humour are marked for the reader. It is clear that the theme, which appeared in a humorous light, is assessed by the reader in different ways someone agrees to laugh at the proposed occasion, someone does not. But when we see that there is no humour in the text, that "everything is serious", we understand that this is a special theme (this is how news is presented about, for example, catastrophes or the deaths of famous people). Of the more than forty analysed issues, there was not a single instance in which the news about the disaster or someone's death had humorous colouring.

Humour acts in the evening issues of the Internet media Meduza as a means of actualizing the news event. The most important communicative task in professional media news environments is the selection of events for the news agenda; the specificity of the news events dictates the humorous means that will be used to promote news in the issue. The use of humour can thus be seen as a strategy to inform the researched news media.

The analysed material (EM newsletters) was considered a polycode hypermedia text, or a system of text blocks and paratextual elements. We have shown that the newsletter's news messages are created in the format of compressed packagings with embedded active links. The unfolding of packagings depends on the intentions of the addressee, but the text organization of the newsletter directs this process. The tools to create humour in the studied media are varied: connections are built between text-packagings, each block and the whole hypermedia text; contrastive focus and change of empathy positions (in the text, visual packagings, the 
paratext and in the newsletter as a whole) are also created based on humorous genres of online communication (in particular pictures).

The way EM represents news facilitates the emergence of an added layer of perspective on events, things and people. The editors try to use this added layer to bring its hypothetical reader to co-reflection. We can say that the editorial position is formed on the level of publication language. This position is based on the axiological principles of liberal-democratic values, because "the liberal-democratic polity may be uniquely friendly to humorous citizens" (Basu 1999).

It was important for us to analyse the material from such perspectives, which can be presentative in the study of other media in our key. The undertaking of such research will mean that our proposed methods can evolve towards a deeper analysis of humour in general.. It seems to us that modern media not only actively use humour, but also develop new forms of humour with the help of new tools.

\section{Acknowledgements}

The study was carried out with the financial support of the RSF: grant 19-18-00530 "Humour as a communicative resource in the digital news environment". The authors also express their deep gratitude to the colleagues of the Department of Medialinguistics of St. Petersburg State University for their advice and comments.

\section{Notes}

${ }^{1}$ By news event we mean here the referential content of the text published in the status

2 The tests, as well as advertising texts, prepared jointly with the sponsors, were not included in our card files.

\section{References}

Ainutdinov A. S. (2010). Karikatura kak tip izobrazheniya komicheskoj intencii v sovremennyh rossijskih pechatnyh [Caricature as a type of comic intention image in modern Russian print media]. Yekaterinburg: Ural state University.

Alonso, P. (2018). Satiric TV in the Americas: Critical metatainment as negotiated dissent. Retrieved June 2018 from Oxford Scholarship Online. DOI: 10.1093/oso/9780190636500.001.0001.

Attardo, S. (1994). Linguistic Theories of Humour. N. Y.: Mouton de Gruyter.

Bakhtin, M. M. (1990 [1965]). Tvorchestvo Fransua Rable $i$ narodnaya kul'tura Srednevekov'ya i Renessansa [Francois Rabelais Creativity and folk culture of the middle Ages and the Renaissance]. Moskau: Hudozhestvennaya literatura.

Basu, S. (1999). 'Dialogic Ethics and the Virtue of Humour'. The Journal of Political Philosophy 7 (4), pp. 378-403. DOI:10.1111/1467-9760.00082.

Baum, M. A. (2003). Soft News Goes to War: Public Opinion and American Foreign Policy in the New Media Age. Princeton, NJ: Princeton University Press.

Becker, A. B. (2014). 'Humiliate my enemies or mock my friends? Applying disposition theory of humour to the study of political parody appreciation and attitudes toward candidates'. Human Communication Research 40 (2), pp. 137-160. Retrieved May 28, 2019 from https://doi.org/10.1111/hcre.12022. 
Bolter J. D. (1991). The writing space: the computer, hypertext, and the history of writing. Hillsdale, New York.

Brodie, I. (2018). 'Pretend News, False News, Fake News: The Onion as Put-On, Prank, and Legend'. Journal of American Folklore 131 (522), pp. 451-459.

Brookey, R. \& Gray, J. (2017). "Not merely para": continuing steps in paratextual research'. Critical Studies in Media Communication 34 (2), 101-110. DOI: 10.1080/15295036.2017.1312472.

Brzozowska, D. (2013). 'Demotivators as a new type of media texts'. Media linguistics 2, pp. 124-126. Retrieved May 28, 2019 from https://elibrary.ru/item.asp?id=22925086.

Bugaeva, I. V. (2011). 'Demotivatory kak novyj zhanr v internet-kommunikacii: zhanrovye priznaki, funkcii, struktura, stilistika' [Demotivators as a new genre in Internet communication: genre features, functions, structure, style]. Style 10. Retrieved May 28, 2019 from http://www.rastko.rs/filologija/stil/2011/10Bugaeva.pdf.

Bucaria, C. (2004) 'Lexical and syntactic ambiguity as a source of humour: The case of newspaper headlines', Humour. International Journal of Humour Research 17 (3), pp. 279309.

Chafe, W. L. (1976). 'Givenness, Contrastiveness, Definiteness, Subjects, Topics, and Point of View', in Ch. N. Li (ed.), Subject and Topic, Academic Press, New York, pp, 27-55.

Chafe, W. (2008). 'Rol' introspektsii, nablyudeniya i eksperimenta v ponimanii myshleniya' [The role of introspection, observation, and experiment in understanding thinking]. [Transl. from English by E.V. Prozorova]. Voprosy yazykoznaniya 4, 78-88.

Chattoo, C.B. \& Green-Barber, L. (2018). 'An investigative journalist and a stand-up comic walk into a bar: The role of comedy in public engagement with environmental journalism'. Journalism. https://doi.org/10.1177/1464884918763526.

Collings, B. (2018). 'British dark comedy television and the bodily aesthetics of the "Proper person"”. Comedy Studies Volume 9, Issue 1, 2 January 2018, pp. 63-75. DOI: 10.1080/2040610X.2018.1437162

Conners, J. L. (2007). 'Popular culture in political cartoons: Analyzing cartoonist approaches'. PS: Political Science and Politics 40 (2), pp. 261-265. DOI: 10.1017/S1049096507070400.

Crawford, A. (2009). “'Oh Yeah!”: Family Guy as Magical Realism?'. Journal of Film and Video 61 (2), pp. 52-69.

Duskaeva, L. R. (2014). 'Rechevaya struktura novostnyh tekstov setevyh izdanij' [Speech structure of news nexts in networks editions]. Perm university bulletin. Russian and foreign philology 1 (25), pp. 179-183.

Duskaeva, L. R. (2015). 'Linguo-Praxiological Analysis of the Arts Media-Discourse'. Research Journal of Applied Sciences 10, pp. 17-21. DOI: 10.3923/rjasci.2015.17.21.

Duskaeva, L. R. \& Vasileva V. V. \& Malyshev A. A. \& Konyaeva Yu. M. \& Redkina T. Yu. (eds.) (2018). Medialingvistika $v$ terminakh $i$ ponyatiyakh: slovar'-spravochnik [Medialinguistics in terms and concepts: dictionary-reference]. Moscow: Flinta.

Esralew, S. \& Young, D. G. (2012). The influence of parodies on mental models: Exploring the Tina Fey-Sarah Palin phenomenon. Communication Quarterly 60 (3), pp. 338-352. DOI: 10.1080/01463373.2012.688791

Evening Meduza, Retrieved from https://telegramfor.me/chan.php?id=meduzaevening

Feldman, O. (1995). 'Political Reality and Editorial Cartoons in Japan: How the National Dailies Illustrate the Japanese Prime Minister'. Journalism \& Mass Communication Quarterly 72 (3), pp. 571-580. DOI: 10.1177/107769909507200308.

Galliulina, A. F. (2012). 'Tipologiya komicheskogo kontenta sovremennogo otechestvennogo televideniya' [Typology of comic content of the modern domestic TV]. Nauka o cheloveke: gumanitarnye issledovaniya 2 (10), pp. 195-199. 
Genette, G. (1997). Paratexts: Thresholds of interpretation. [trans. J. E. Lewin]. Cambridge: Cambridge University Press.

Golikov, A. S. \& Kalashnikova, A. A. (2010). `Demotivatory v internet-kommunikacii: genezis, smysl, tipologiya' [Demotivators in Internet communication: Genesis, meaning, typology]. Bulletin of Kharkiv state University, 16 pp. 124-130.

Grice, H. P. (1975). 'Logic and conversation', in Cole, P. \& Morgan, J. L. (eds.), Syntax and semantics 3, N. Y.: Academic Press, pp. 41-58.

Haritonova, E. V. (2012). 'Tendenciya k ekonomichnosti v sovremennom russkom sintaksise (na materiale pressy)' [The tendency to economy in modern Russian syntax (by the material of the press)], News of Volgograd state pedagogical University. Linguistics 8 (72), pp. 8992.

Havig, A. (2010). Fred Allen's radio comedy. Stephens College. Columbia, MO, United States.

Henry, M. A. (2012) The Simpsons, satire, and American culture. Richland College, United States.

Hunt, L. (2013). Cult British TV Comedy: From Reeves and Mortimer to Psychoville. Manchester: Manchester University Press.

Hutchings, P. (2007). 'Welcome to Royston Vasey: Grotesque Bodies and the Horror of Comedy in The League of Gentlemen'. Intensities: The Journal of Cult Media, 4. Retrieved May 28, 2019 from https://intensitiescultmedia.files.wordpress.com/2012/12/hutchingswelcome-to-royston-vasey.pdf

Kiseleva, E. I. (2018). 'Transformaciya politicheskogo yumora v informacionnorazvlekatel'nyh programmah na sovremennom rossiiskom televidenii na primere teleshou Pervogo kanala "ProzhektorPerisHilton" i "Vechernij Urgant" (2009-2018 gg.)' [Transformation of political humour in informational and entertain programs on modern Russian television on the material of the First Channel TV shows "ProjectorPerisHilton" and "Evening Urgant" (2009-2018)], in MNSK-2018, Novosibirsk: Novosibirsk State University. pp. 27-28. Retrieved May 12, 2019 from https://elibrary.ru/download/elibrary_35385900_25832345.pdf

Kosova, V. A. \& Sun Miao (2015). 'Funkcional'naya semantika univerbov v russkih sociolektah' [Functional semantics of univerbs in russian sociolects]. Filologiya i kul'tura 3 (41), pp. 67-74.

Krifka, M. (2008). 'Basic notions of information structure'. Acta Linguistica Hungarica 55 (34), pp. 243-276. DOI: 10.1556/ALing.55.2008.3-4.2.

Krivoruchko, M. V. (2019). 'Televizionnye predpochteniya kak prediktory deviantnogo povedeniya $\mathrm{v}$ podrostkovom vozraste' [Television preferences as predictors of deviant behavior in adolescial age]. Herald of Omsk University. Series Psychology 1, pp. 57-67. DOI: $10.25513 / 2410-6364.2019 .1 .57-67$.

Krivoruchko, M. V. \& Stepanova, A. S. (2010). 'Osobennosti gendernyh ustanovok molodezhi s raznoi stepen'yu uvlechennosti teleperedachei "Comedy Club»' [Features of gender attitudes of young people with varying degrees of interest in the TV show Comedy Club]. Herald of Omsk University. Series Psychology 2, pp. 27-31.

Lashchuk, O. R. (2004). Redaktirovanie informacionnyh soobshchenij [Edit informational messages], Moscow: Aspect Press.

Lim, M. \& Moufahim, M. (2015). 'The spectacularization of suffering: an analysis of the use of celebrities in 'Comic Relief' UK's charity fundraising campaigns'. Journal of Marketing Management 31 (5-6), pp. 525-545.

Mann, R. (2016). 'The Bibi Sitter and the Hipster: the new comical political discourse'. Israel Affairs 22: 3-4, pp. 788-801. DOI: 10.1080/13537121.2016.1174379

McCoy, S. (2003). 'Connecting Information Structure and Discourse Structure through "Kontrast": The Case of Colloquial Russian Particles -TO, ŽE, and VED'. Journal of Logic, 
Language and Information 12: 319-335. Retrieved May 28, 2019 from https://doi.org/10.1023/A:1024110711090.

Mediascope.net. Retrieved from https://webindex.mediascope.net/report?id=211688.

Murzin, L. N. \& Shtern, A. S. (1991). Tekst i ego vospriyatie [The text and its perception]. Sverdlovsk: Ural University.

Panchenko, N. N. (2011). 'Intencional'nyj harakter inkorporirovaniya komicheskogo v anglijskom novostnom diskurse' [The Intentional nature of the incorporation of the comic in English news discourse]. Magister Dixit 2, pp. 192-197.

Panchenko, N. N. (2017a). 'Novostnoj kontent: dostovernost' i fikcional'nost' novyh media' [News content: authenticity and fictionality of new media], in Kommunikativnoe prostranstvo kul'tury. Oryol: Oryol state Institute of culture, pp. 225-228.

Panchenko, N. N. (2017b). 'Kriticheskij modus konvergentnogo komicheski-novostnogo diskursa' [Critical mode of convergent comic-news discourse]. Uspekhi sovremennoj nauki 2(2), pp. 152-157.

Parfionov, L. Parfenon [Parfenon]. Retrieved June 10, 2019 from https://www.youtube.com/watch?v=v21 mTm2mLeE.

Peifer, J. T. \& Myrick, J. G. (2019). 'Risky satire: Examining how a traditional news outlet's use of satire can affect audience perceptions and future engagement with the news source'. Journalism. Retrieved May 28, 2019 from https://doi.org/10.1177/1464884919833259.

Rabkina N. V. \& Kameneva V. A. (2013). 'Funkcional'nyj i pragmaticheskij potencial demotivatorov kak vizual'no-verbal'noj formy sovremennoj internet-kommunikacii' [The functional and pragmatic potential of demotivators as a visual-verbal form of modern internet communication]. Political linguistics 1 (43), pp. 144-151.

Raskin, V. (1985). Semantic Mechanisms of Humour. Dordrecht: D. Reidel Publishing Company.

Refaie, E. E. (2003). 'Understanding visual metaphor: The example of newspaper cartoons'. Visual Communication 2 (1), pp. 75-95. DOI: 10.1177/1470357203002001755.

Remizov, A. V. \& Movchan A. S. (2016). Priroda komicheskogo i formy ego reprezentacii v sovremennom rossijskom televidenii [The Nature of the comic and the form of its representation in modern Russian television]. Bulletin of the Moscow state University of culture and arts 3 (71), pp. 93-98.

Shilikhina, K. M. (2019). 'Yumoristicheskie fejkovye novosti kak kommunikativnaya tekhnologiya i zhanr onlajn-kommunikacii' [Humorous fake news as a communicative technology and genre of online communication]. Izvestiya Volgograd state pedagogical University 5 (138), pp. 139-143.

Shmatkova, A. (2015). 'Il'ya Krasil'shchik: "Straha net. Est' vostorg i uzhas" [Iliya Krasilishchik: "Here is no Fear. There is delight and horror"]. April 21. Roem.ru. Retrieved May 28, 2019 from https://roem.ru/21-04-2015/192419/krasilschik-meduza-no-scare/.

Shokina, A. B. (2008). 'Yazykovaya kompressiya v reklamnom tekste' [Linguistic compression in the advertising text]. Mediaskop, 2. Retrieved May 28, 2019 from https://elibrary.ru/item.asp?id=17030707.

Sienkiewicz, M. (2018). 'The Carnival's Edge: Charlie Hebdo and Theories of Comedy'. Jewish History vol. 32, Is. 1. November 1, pp. 19-32.

Splendore, S. \& Domaneschi, L. (2017). 'Entertainment is serious stuff: The politicisation of everyday laughs'. Contemporary Italian Politics vol. 9, Is. 3, pp. 302-317.

Subbotina, N. D. (2015). 'Oficial'nyj i karnaval'nyj - dva tipa prazdnika' [Official and carnival - two types of holiday]. Gumanitarnyj vector 2 (42), pp. 40-47.

Surganova, E. (2014). 'Galina Timchenko: "Nikto iz nas ne mechtaet delat' Kolokol"' [Galina Timchenko: "None of us wants to make a Bell']. September 15. Forbes. Retrieved April 
28, 2019 from https://www.forbes.ru/kompanii/internet-telekom-i-media/267611-galinatimchenko-nikto-iz-nas-ne-mechtaet-delat-kolokol.

Teplyashina, A. N. (2007). Tvorcheskaya priroda komicheskogo: zhanrovaya paradigma sovremennoj zhurnalistiki [The Creative nature of the comic: the genre paradigm of modern journalism]. St Petersburg: St Petersburg state university.

Vasileva V. V. \& Duskaeva L. R. (2016). 'Kommunikativnyj scenarij prizyva v massmedijnom polikodovom tekste: proyavleniya ekstremistskogo vyskazyvaniya' [Communicative scenario of the appeal in the mass media polycode text: manifestations of extremist statements], in Kazanskij, N.N. (ed.) Acta linguistica petropolitana XII(3), pp. 395-405.

Vasileva V. V. \& Redkina T. Yu. (2019). 'Medialingvisticheskie principy v organizacii ekspertnogo issledovaniya' [Media linguistically principles in the organization of expert research], in Voroncov, A. V. (ed.) Ekspertnaya deyatel'nost'v sfere gumanitarnyh nauk [Expert activity in the field of Humanities]. SPb.: Publishing house RGPU named after A. I. Herzen.

Vasileva, V.V. \& Salimovsky, V.A. (2010) 'Chlenimost' vyskazyvaniya v dialoge' [The boundaries of utterances in the dialogue], in Bolotnova N.S. (ed.), Russkaya rechevaya kul'tura i tekst. Tomsk: Publishing of Tomsk CNTE, pp. 284-290.

Vasileva, V. V. (2017) 'Anekdot v professional'nom mediatekste: pereprofilirovanie rechevogo zhanra' [Anecdote in professional media text: re-profiling of the speech genre]. Media Linguistics 4 (19), pp. 80-89. Retrieved April 12, 2019 from https://medialing.ru/anekdotv-professionalnom-mediatekste-pereprofilirovanie-rechevogo-zhanra/.

Voroshilova, M. B. (2006). 'Kreolizovannyj tekst: aspekty izucheniya' [Creolized text: aspects of the study]. Political linguistics 20, pp. 180-189.

Xenos, M. A. \& Becker, A. B. (2009). 'Moments of Zen: Effects of the daily show on information seeking and political learning'. Political Communication, 26 (3), pp. 317-332.

Young, D. G. (2013). 'Laughter, learning, or enlightenment? Viewing and avoidance motivations behind The Daily Show and The Colbert Report'. Journal of Broadcasting \& Electronic Media 57 (2), pp. 153-169.

Yue, X. D. \& Jiang, F. \& Lu, S. \& Hiranandani, N. A. (2016). 'To Be or Not To Be Humorous? Cross Cultural Perspectives on Humour'. Frontiers in Psychology. November. DOI: 10.3389/fpsyg.2016.01495. 